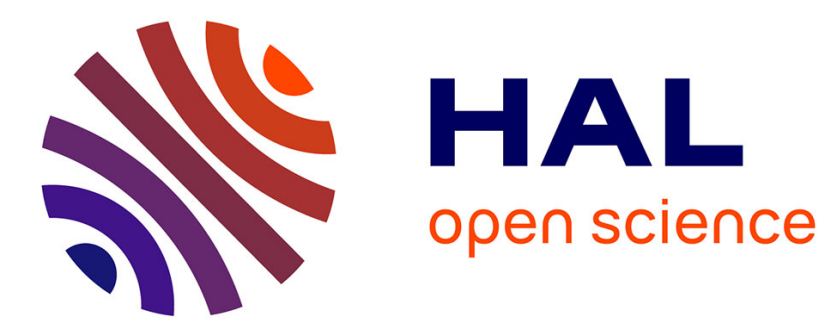

\title{
Towards integrating toxicity characterization into environmental studies: case study of bromine in soils
}

Tatiana Bratec, Nienke Kirchhübel, Natalia Baranovskaya, Bertrand Laratte, Olivier Jolliet, Leonid Rikhvanov, Peter Fantke

\section{- To cite this version:}

Tatiana Bratec, Nienke Kirchhübel, Natalia Baranovskaya, Bertrand Laratte, Olivier Jolliet, et al.. Towards integrating toxicity characterization into environmental studies: case study of bromine in soils. Environmental Science and Pollution Research, 2019, 26 (19), pp.19814-19827. 10.1007/s11356019-05244-5 . hal-02143914

\section{HAL Id: hal-02143914 https://hal.science/hal-02143914}

Submitted on 29 May 2019

HAL is a multi-disciplinary open access archive for the deposit and dissemination of scientific research documents, whether they are published or not. The documents may come from teaching and research institutions in France or abroad, or from public or private research centers.
L'archive ouverte pluridisciplinaire HAL, est destinée au dépôt et à la diffusion de documents scientifiques de niveau recherche, publiés ou non, émanant des établissements d'enseignement et de recherche français ou étrangers, des laboratoires publics ou privés. 


\title{
Towards integrating toxicity characterization into environmental studies: case study of bromine in soils
}

\author{
Tatiana Bratec ${ }^{1,2} \cdot$ Nienke Kirchhübel $^{3} \cdot$ Natalia Baranovskaya ${ }^{2} \cdot$ Bertrand Laratte $^{1,4,5} \cdot$ Olivier Jolliet $^{6}$. \\ Leonid Rikhvanov ${ }^{2} \cdot$ Peter Fantke ${ }^{3}$
}

\begin{abstract}
Pollution from bromine and some of its related compounds is currently unregulated in soil from Russia and other countries, and tools for sound assessment of environmental impacts of bromine contamination are largely missing. Hence, assessing potential implications for humans and ecosystems of bromine soil contamination is urgently needed, which requires the combination of measured soil concentrations from environmental studies and quantified potential toxicity impacts. To address this need, we used data from an experimental study assessing bromine in soils (384 samples) of Tomsk oblast, Russia, starting from measured concentrations obtained by Instrumental Neutron Activation Analysis in an earlier study. From these data, we calculated the bromine mass in soils and used these as starting point to characterize related cumulative impacts on human health and ecosystems in the Tomsk region, using a global scientific consensus model for screening-level comparative toxicity characterization of chemical emissions. Results show that the combination of sampling methodology with toxicity characterization techniques presents a new approach to be used in environmental studies aimed at environmental assessment and analysis of a territory. Our results indicate that it is important to account for substance-specific chemical reaction pathways and transfer processes, as well as to consider region-specific environmental characteristics. Our approach will help complement environmental assessment results with environmental sustainability elements, to consider potential tradeoffs in impacts, related to soil pollution, in support of improved emission and pollution reduction strategies.
\end{abstract}

Keywords Bromine contamination $\cdot$ Tomsk oblast $\cdot$ Characterization factors $\cdot$ USEtox $\cdot$ Human toxicity $\cdot$ Freshwater ecotoxicity

\section{Introduction}

Bromine (Br), a chemical element belonging to the group of halogens, has the atomic number of $35 . \mathrm{Br}$ is a typical trace element and its major sources are mostly natural: seawater, salt lakes and lake brines, highly mineralized reservoir waters, and the waters of oil deposits (Vinogradov 1939; Chemical Encyclopedia 1988; Emsley 1989). However, bromine

https://doi.org/10.1007/s11356-019-05244-5

Tatiana Bratec

tatiana.bratec@utt.fr

1 Research Centre for Environmental Studies and Sustainability, University of Technology of Troyes, CNRS, ICD, 12 Rue Marie Curie CS 42060, F-10004 Troyes Cedex, France

2 Division for Geology, School of Earth Sciences and Engineering, National Research Tomsk Polytechnic University, 30 Lenin Avenue, 634050 Tomsk, Russia
3 Quantitative Sustainability Assessment, Department of Technology, Management and Economics, Technical University of Denmark, Produktionstorvet 424, $2800 \mathrm{Kgs}$. Lyngby, Denmark

4 Arts et Métiers ParisTech, I2M, UMR 5295, F-33400 Talence, France

5 APESA-Innovation, Pôle Territorial de coopération économique social et environnemental, 23 Rue Hélène Boucher, 40220 Tarnos, France

6 Environmental Health Sciences, University of Michigan, 1415 Washington Heights, Ann Arbor, MI 48109-2029, USA 
contamination could appear due to human activities as far as bromine and its compounds are used in numerous areas such as chemical and food industries, medicine, pharmaceutics, agriculture, and nuclear industry (Filov 1988; Greenwood and Ershno 2008; Yoffe et al. 2013). If not specified otherwise, we use the term "bromine" to refer to the element in its various forms including related compounds.

Bromine is considered as one of the essential elements (McCall et al. 2014). However, there is considerable data indicating its toxic effects. Since bromine can be emitted to the environment in the form of different ions or compounds, related toxic effects could vary significantly from one compound/form to another. The literature data on toxicity presented hereafter describe the toxicity of bromide $\left(\mathrm{Br}^{-}\right)$that is the anion of the element bromine $\left(\mathrm{Br}_{2}\right)$. In some cases, bromide could provoke phytotoxicity, since it could replace chlorine and affect changes in cell membrane permeability (Nazer et al. 1982; Kabata-Pendias 2010). Likewise, animal studies describe bromide as toxic at varying dose levels (van Leeuwen et al. 1983; World Health Organization 1988; IUCLID 2000).

With respect to effects on human health, bromine is reported to play an important role in the appearance and development of various diseases (Valdés et al. 2012). Elevated bromine contents have been found in the heart tissue of patients suffering from uremia (Pehrsson and Lins 1983), dilated cardiomyopathy (Bumbalova et al. 1991), and sickle-cell anemia, and also in cancerous breast tissue and in the brain of patients with Alzheimer's disease (Ehmann and Vance 1996), and others.

The widespread use of bromine today and the potential danger caused by anthropogenic entry of the element and its compounds into the environment, as well as its negative impact on living organisms, determine the existence of the regulatory standards in some countries. For example, in Russia, elemental bromine and its several compounds are standardized (i.e., maximum permissible concentrations are set) in workplaces air (GN 2.2.5.1313-03 2003) and ambient air in public areas (GN 2.1.6.1338-03 2003). According to these standards, bromine presents a class II danger, i.e., is highly dangerous. There are also established hygienic standards for bromide in water in Russia (GN 2.1.5.1315-03 2003). There are no limit values for bromide in water, established by the WHO, according to which "it occurs in drinking water at concentrations well below those of health concern" (World Health Organization 2011), but some recommendation values are proposed as an alternative (World Health Organization 2009). However, today, there is a significant gap in the establishment of standards or recommendations for bromine levels in soils.

Studies show that the content of bromine in soils usually ranges from 5 to $40 \mathrm{mg} / \mathrm{kg}$ (Kabata-Pendias 2010); according to Vinogradov (1957), the average content is $5 \mathrm{mg} / \mathrm{kg}$. In accordance with the electronic structure of the bromine atom, the element in soils can be found in the form of various ions: $\mathrm{Br}^{-}$(the most widespread form), $\mathrm{BrO}^{-}, \mathrm{BrO}^{-}, \mathrm{BrO}^{-}$, as well as organic compounds (Konarbaeva 2008). A major contribution to studying $\mathrm{Br}$ in soils was made by Vinogradov (1957), Yamada (1968), Yuita (1983), Yuita et al. (1982), Konarbaeva (2008), and Kabata-Pendias (2010).

In the present paper, the area of interest is Tomsk oblast, an administrative region of the Russian Federation, where chemical and oil industries, together with agriculture, are among the main contributors to chemical pollution of soils (Banks et al. 2000; Zhornyak et al. 2016). A recent study (Perminova et al. 2017) showed that among 26 chemicals identified in the soils of Tomsk oblast, bromine concentrations are significantly higher compared with background soil concentrations from local park areas and levels found in soils of other regions of Russia. However, the mechanisms behind bromine contamination in soils of Tomsk oblast, along with the associated impacts on human and environmental health, are still largely unclear.

In response, we propose to use a modeling approach helping to determine current bromine soil contamination patterns in Tomsk oblast and to screen potential related negative impacts on humans and the environment in order to better understand and mitigate bromine-related emissions and impacts. Measured bromine concentrations in our case are not bromine emitted itself, but the total possible bromine found in soils in different forms. Since bromine could originate from different sources in various forms or/and being presented as a compound, it is important to account for the correct emission forms that will ultimately be present in the environment. However, there is currently no screening-level modeling framework available for assessing the fate and exposure of inorganic substances that are not metal ions (Kirchhübel and Fantke, 2019). To demonstrate this issue, we are testing in the present study different modeling assumptions in a global scientific consensus model for screening-level characterization of fate, exposure, and effects of chemical emissions (Rosenbaum et al. 2008; Henderson et al. 2011). More specifically, we will model bromine compound emissions on the one hand in the same way as metal ions are modeled, and on the other hand in the same way as organic substances are modeled. This allows us to contrast the different assumptions and provide some input for developing new methods for consistently assessing fate, exposure, and effects of inorganic substances other than metal ions.

Quantifying life cycle toxicity impacts based on existing actual pollutant levels in soil will, in addition, be useful in complementing pollutant threshold levels by uncovering potential tradeoffs between different multi-media fates and multipathway exposures, related to soil contaminants contributing to potentially negative impacts on humans and the environment (Fantke et al. 2018a, 2018b). In the present study, we focus on the following three objectives: (1) to determine the cumulative mass of bromine in soil in the different districts of Tomsk oblast and discuss potential sources; (2) to characterize cumulative 
human toxicity and ecotoxicity impact potentials of bromine mass in soils of Tomsk oblast; and (3) to identify existing challenges of combining environmental studies with screeninglevel toxicity characterization, and to discuss future research needs as input to develop operational methods for mitigating contamination from emissions of inorganic substances.

\section{Methodology}

\section{Study area}

Tomsk oblast is a region of the Russian Federation situated in the south-eastern part of the largest plain in the world - the West Siberian. The area of Tomsk oblast is $316.9 \mathrm{~km}^{2}$, which is larger than most European countries (Evseyeva 2001). Tomsk oblast borders with Krasnoyarsk Krai in the east, Tyumen and Omsk oblasts in the west, and Novosibirsk and Kemerovo oblasts in the south. This region includes 16 administrative districts (Fig. 1). The administrative center is the city of Tomsk. The region is inhomogeneous with the majority of the population living in the southern part of the Tomsk oblast near rivers, roads, and railroads.
The oblast is rich in natural resources, mainly in crude hydrocarbons (1.5 billion tons of oil and 757 billion tons of gas (Evseyeva 2001). The area is further characterized by a wide range of other types of mineral resources including sedimentary iron ores, complex zircon-ilmenite ores, occurrences of gold, platinum, zinc and bauxites, peat, and coal. In addition, Tomsk oblast is heavily forested with a total wood stock of 2760 million $\mathrm{m}^{3}$ (Evseyeva 2001).

Its richness in natural resources is the main reason for the great number of industrial complexes in this region, which are associated with emissions of a large number of chemicals into the environment and related contamination and health problems. The biggest environmental problems of the region have been identified in the Tomsky district, where about 33 large industrial facilities of different sectors are situated. Among them, there are the country's largest petrochemical plant and the nuclear cycle plant as well as different energy processing and agro-industrial complexes. Additional zones, posing a potential threat for humans and the environment, mainly through soil contamination, include areas of oil and gas extraction and processing and buried radioactive waste as well as areas of intensive forest harvesting and fires (Rikhvanov et al. 2006).

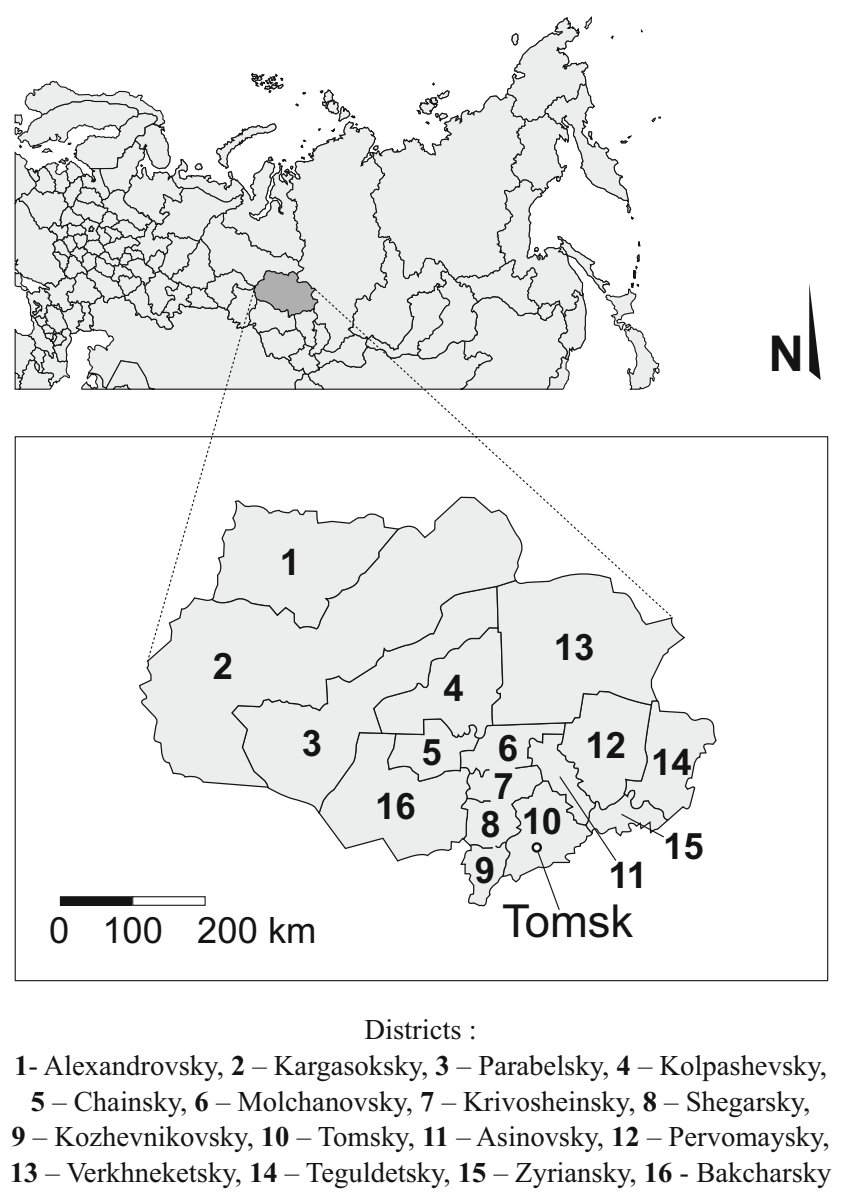

Fig. 1 Geographical location of Tomsk oblast within the territory of the Russian Federation and its administrative division into districts (adapted from Evseyeva 2001) 


\section{Bromine soil inventory data}

Soil sampling was carried out in the territory of Tomsk oblast between 2004 and 2015. Since sampling was carried out over a long period of time on a large area, it was necessary to maximally avoid the impact of possible external factors that could affect the concentration of the element in soils (for example, precipitations during sampling in one district and their absence in another). For this purpose, a methodological approach, consisting in synchronicity or maximum convergence of soil selection points in time, was used. Thus, all soil samples of the same year were taken across Tomsk oblast districts within the short period (3-5 days). In addition, it was also important to ensure the synchronicity of soil sampling in space. Therefore, the samples taken in each subsequent year were selected at identical points as the previous ones (GPS devices were used for this purpose). Sampling results are discussed in detail by Perminova et al. (2017) and are the starting point for obtaining the bromine soil inventory used in the present study. The following brief description summarizes the main sampling steps. Soils, used for agricultural purposes, were taken in 75 settlements in 14 out of the total of 16 administrative districts of the region, noting the presence or absence of organic fertilizers. The Alexandrovsky and Kargasoksky districts were not included in the study due to accessibility problems. The total number of soil samples was 384. Soil sampling from the topsoil 0-10 $\mathrm{cm}$ (the upper fertile layer) was conducted in the last decade of March to early April, using the "envelope" method. Five subsamples of $0.2 \mathrm{~kg}$ were selected from each soil pit, giving a total sample of $1 \mathrm{~kg}$ from each place. All samples were packed in thick wrapping paper. Pre-treatment of soil samples included the following steps: drying at room temperature, removal of foreign inclusions (vegetation particles, stones, etc.), grinding, and progressive sieving (initial sieve hole diameter was $2.5 \mathrm{~mm}$, followed by $1 \mathrm{~mm}$ ). All procedures were carried out according to normative standards (GOST 17.4.4.02-84, 1984). A subsample of $100 \mathrm{mg}$ was packed in an aluminum foil for further analysis.

For the quantitative determination of bromine in soil samples, highly sensitive Instrumental Neutron Activation Analysis (INAA) was used. INAA is based on the detection of radioactive nuclides generated during the irradiation of test samples by a neutron flux. Irradiation was carried out by thermal neutrons with an integrated dose of $2 \times 10^{13} \mathrm{n} /\left(\mathrm{cm}^{2} \mathrm{~s}\right)$ at the research reactor IRT-T (Tomsk typical research reactor) of the Research Institute of Nuclear Physics at National Research Tomsk Polytechnic University in Tomsk, Russia. The sample exposure time was $20 \mathrm{~h}$. The measurements were performed on a gamma spectrometer with a germanium-lithium detector. A comparative evaluation of the results obtained by the INAA with national (Russian) and international standards (IAEA) was carried out. The results were found to be satisfactory within the error of established concentrations of $\pm 5 \%$. The data obtained from the INAA were analyzed in Microsoft Excel and Statistica 8.0 software to evaluate statistical parameters. All data are further described in Perminova et al. (2017).

\section{Characterizing human toxicity and freshwater ecotoxicity}

To characterize human toxicity and ecotoxicity impacts based on bromine soil concentrations from Perminova et al. (2017), we first calculated the total mass of bromine in agricultural soils of the region as follows:

$m_{i}=C_{i} \times V_{\text {soil }} \times \rho_{\text {soil }}$

with $m_{i}\left(\mathrm{~kg}_{\mathrm{Br} \text { emitted }}\right)$ the total bromine mass in agricultural soils of the region, calculated from the measured bromine concentration in soil identified by INAA, $C_{i}$ (measured in $\mathrm{mg}_{\mathrm{Br} \text { in soil }} / \mathrm{kg}_{\text {soil }}$ and multiplied by $10^{-6}$ to arrive at $\mathrm{kg}_{\mathrm{Br}}$ in soil $\left(\mathrm{kg}_{\text {soil }}\right)$, the bulk soil volume in a considered region, $V_{\text {soil }}$ $\left(\mathrm{m}^{3}{ }_{\text {soil }}\right)$, and the bulk soil density, $\rho_{\text {soil }}\left(\mathrm{kg}_{\text {soil }} / \mathrm{m}^{3}\right.$ soil $)$.

We then applied version 2.02 of the UNEP-SETAC scientific consensus model USEtox (www.usetox.org), which is widely accepted for toxicity characterization in life cycle impact assessment and other comparative assessment frameworks (Westh et al. 2015). The substance databases of USEtox already include more than 3000 characterized organic substances and 27 metal ions. However, the inorganic substance bromine (CAS 7726-95-6) is not included. Hence, in our study, we aimed at developing human toxicity and freshwater ecotoxicity characterization factors $(\mathrm{CFs})$ for bromine. Toxicity characterization factors express potential toxicity-related impacts on humans or ecosystems per unit of a particular chemical, emitted to a specific environmental compartment. Since USEtox is currently not applicable for inorganic substances other than metal ions, we developed preliminary CFs for bromine following, as the first proxy, the existing characterization in USEtox for both metal ions and organic substances, thereby acknowledging that both approaches have to be adapted to fully address the complex transformation of bromine in soils and potentially other media. This, however, is beyond the scope of the current study, where we focus on presenting a proof-of-concept framework for combining measured concentrations of soil contaminants consistently with multi-compartmental modeling to characterize impact on human toxicity and freshwater ecotoxicity, and identify associated future research needs.

For characterizing bromine, we calculate the cumulative toxicity impact score $I S$ for a mass of chemical $x$ (in our study bromine, Br) emitted to (or in our case initially present in) compartment $i$ (in our study soil):

$I S_{x, i}=C F_{x, i} \times m_{i}$

with $I S_{x, i}$ as toxicity impact score (for human toxicity, disability-adjusted life years (DALY); for freshwater 
ecotoxicity, potentially disappeared fraction (PDF) of species integrated over exposed water volume and time, PDF $\mathrm{m}^{3} \mathrm{~d}$ ), $C F_{x, i}$ as a characterization factor (for toxicity-related impacts on human health, DALY $/ \mathrm{kg}_{\mathrm{Br}}$ emitted; for ecotoxicity-related impacts on ecosystem quality, PDF $\mathrm{m}^{3} \mathrm{~d} / \mathrm{kg}_{\mathrm{Br} \text { emitted }}$ ), and $m_{i}$ as the chemical mass emitted or by extension in our case initially present in the soil compartment $\left(\mathrm{kg}_{\mathrm{Br}}\right.$ emitted $)$.

Characterization factors are derived from four factors, namely a fate factor, $F F_{x, i}$ (d) representing the residence time of the substance in soil; an exposure factor, $X F_{x, i}$ (for human exposure, $\mathrm{kg}_{\mathrm{Br} \text { intake }} / \mathrm{d}$ per $\mathrm{kg}_{\mathrm{Br}}$ in soil ; for ecosystem exposure, $\mathrm{kg}_{\mathrm{Br} \text { bioavailable }} / \mathrm{kg}_{\mathrm{Br} \text { in soil }}$ ); an effect factor, $E F_{x}$ (for human toxicity effects, disease cases $/ \mathrm{kg}_{\mathrm{Br}}$ intake; for freshwater

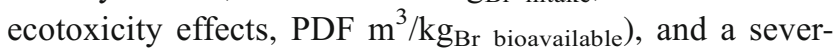
ity factor, $D F$, translating impacts into damages (for human health damages, DALY/disease case; for ecosystem quality damages, PDF/PAF with PAF as potentially affected fraction of exposed species):

$C F_{x, i}=D F \times E F_{x} \times X F_{x, i} \times F F_{x, i}$
As demonstrated by Heijungs (1995), the steady state assumption of a level III multi-media model like USEtox is equivalent to calculating the cumulative impacts of an initial pulse emission into soil (or in our case an initial mass in the soil at time zero), integrated up to infinity.

Calculated toxicity impact scores are therefore time-integrated, representing long-term impacts of the existing mass in soil. We discuss two scenarios for future emissions, i.e., assuming that there is no additional emission taking place, or assuming that there is a continuous constant emission flow corresponding to the present mass in soil divided by the residence time of the substance in soil. Fate, exposure, human toxicity, and ecotoxicity effect factors were derived following the USEtox approach. All input data used for calculating CFs for bromine are presented in Table 1.

\section{Landscape data}

Pre-defined landscape data in USEtox 2.0 are given for eight continental and 17 sub-continental regions and are mainly meant

Table 1 Data sources used for characterizing $\mathrm{Br}_{2}$ as metal ion and organic substance in USEtox 2.02

\begin{tabular}{|c|c|c|c|}
\hline Parameter, unit & $\begin{array}{l}\text { Required to characterize } \\
\mathrm{Br}_{2} \text { as organic }(\mathrm{O}) \text { or } \\
\text { inorganic (I) substance }\end{array}$ & Value & Reference \\
\hline Molar mass, $\mathrm{g} / \mathrm{mol}^{(1)}$ & $\mathrm{I}, \mathrm{O}$ & 159.81 & Mendeleev's Periodic Table \\
\hline Partitioning coefficient between octanol and water, $1 / 1$ & $\mathrm{O}$ & 10.72 & $\begin{array}{l}\text { US Environmental Protection } \\
\text { Agency OPPTS (2010) }\end{array}$ \\
\hline Solubility (at $25^{\circ} \mathrm{C}$ ), $\mathrm{mg} / \mathrm{l}$ & $\mathrm{O}$ & 17110 & Gandolli (1999) \\
\hline Vapor pressure (at $25^{\circ} \mathrm{C}$ ), $\mathrm{Pa}$ & $\mathrm{O}$ & 28700 & Lide (1993) \\
\hline Partitioning coefficient between suspended solids and water, $1 / \mathrm{kg}^{(2)}$ & I & 55 & IAEA International Atomic \\
\hline Partitioning coefficient between sediment particles and water, $1 / \mathrm{kg}^{(2)}$ & I & 55 & Energy Agency (2010) \\
\hline Partitioning coefficient between soil particles and water, $1 / \mathrm{kg}^{(2)}$ & I & 55 & \\
\hline Rate constant degradation in air, $1 / \mathrm{s}$ & $\mathrm{I}, \mathrm{O}$ & 0.017 & Fan and Jacob (1992) \\
\hline Average of the log-values of the species-specific averaged eco-toxicity $\mathrm{EC}_{50}{ }^{(3)}$ & $\mathrm{I}, \mathrm{O}$ & -0.27 & According to the USEtox \\
\hline $\begin{array}{l}\text { Human-equivalent lifetime dose per person that causes a non-cancer } \\
\text { disease probability of } 50 \% \text { after inhalation }{ }^{(4)}\end{array}$ & $\mathrm{I}, \mathrm{O}$ & 0.058 & guidelines (Fantke et al. 2017) \\
\hline $\begin{array}{l}\text { Human-equivalent lifetime dose per person that causes a non-cancer } \\
\text { disease probability of } 50 \% \text { after ingestion }\end{array}$ & $\mathrm{I}, \mathrm{O}$ & 3.93 & \\
\hline Bioaccumulation factor in plant roots, $\mathrm{kg}_{\mathrm{veg}} / \mathrm{kg}_{\text {soil }}^{\left({ }^{(6)}\right.}$ & $\mathrm{I}, \mathrm{O}$ & 0.3 & US Environmental Protection \\
\hline Bioaccumulation factor in plant leaves, $\mathrm{kg}_{\mathrm{veg}} / \mathrm{kg}_{\text {soil }}$ & $\mathrm{I}, \mathrm{O}$ & 1.50 & Agency (2005) \\
\hline Biotransfer factor in meat, $\mathrm{d} / \mathrm{kg}_{\text {meat }}$ & $\mathrm{I}, \mathrm{O}$ & 0.025 & \\
\hline Biotransfer factor in milk, $\mathrm{d} / \mathrm{kg}_{\text {milk }}$ & $\mathrm{I}, \mathrm{O}$ & 0.02 & \\
\hline Bioaccumulation factor in fish, $1 / \mathrm{kg}_{\text {fish }}$ & $\mathrm{I}, \mathrm{O}$ & 160 & Kennedy Jr and Strenge (1992) \\
\hline
\end{tabular}

(1) A molecule of bromine is diatomic; the molar mass taken into account was thus for $\mathrm{Br}_{2}$

(2) According to IAEA 2009 (Appendix A-2), organic carbon does not play a major role in partitioning for metals and the same partitioning is assumed, regardless of the soil, suspended sediment or bottom sediment phase

${ }^{(3)}$ Original data source used is US Environmental Protection Agency 2005, where the acute $\mathrm{EC}_{50}$ for Daphnia magna is $1070 \mu \mathrm{g} / 1$ (see Table S1 in Supplementary Materials)

(4) Original data taken from http://gov.uk/government/uploads/system/uploads/attachment_data/file/316642/Bromine_guidance.pdf, where the LOAEL is $20 \mathrm{mg} / \mathrm{kg}$ bw/day, based on a subacute toxicity study in rats (see Table S2 in Supplementary Materials)

${ }^{(5)}$ Original data taken from https://echa.europa.eu/registration-dossier/-/registered-dossier/15150/7/6/3, where the NOAEC is $0.16 \mathrm{mg} / \mathrm{m}^{3}$, based on a subchronic toxicity study in rats

${ }^{(6)}$ Converted from dry weight to wet weight by dividing by a factor of 5 
to be used as sensitivity analysis of default landscape parameters. The territory of the Russian Federation is among the available regions. However, since our study area covers only one region within Russia, we introduced a new set of landscape data reflecting the characteristics of the Tomsk oblast with an overview of all new landscape parameters given in Table 2 .

\section{Results}

\section{Distribution and sources of bromine in soils of Tomsk oblast}

Measured concentrations of bromine determined in soils of the 14 districts of Tomsk oblast are summarized in Table 3 (adapted from Perminova et al. 2017), along with calculated total bromine mass in the soil of each considered district. Average concentrations of bromine across Tomsk oblast districts range from 9.3 $\mathrm{mg} / \mathrm{kg}$ in Tomsky (measured mostly in natural soils, whereas soils in all other districts are agricultural soils) to $39.4 \mathrm{mg} / \mathrm{kg}$ in Bakcharsky with a minimum of $0.5 \mathrm{mg} / \mathrm{kg}$ in Kozhevnikovsky and Tomsky soils and a maximum of $64.9 \mathrm{mg} / \mathrm{kg}$ in Bakcharsky. Average concentrations of bromine in the studied soils remain within the mean worldwide contents (Kabata-Pendias 2010). However, the maximum concentrations of the element in two districts of the region (Tomsky and Bakcharsky) exceed the average world data. Bromine soil concentrations varied most in the Tomsky district $(0.5-59.5 \mathrm{mg} / \mathrm{kg})$ and least in the Shegarsky district $(13-15.6 \mathrm{mg} / \mathrm{kg})$. The histogram of the distribution of bromine content indicates close to normal distribution for the soils of the Tomsk oblast. When analyzing the distribution of bromine concentrations in the soils by district, we can observe that it is not conformed to the theoretical law on the normal distribution, with the exception of Kozhevnikovsky, Tomsky, and Bakcharsky districts (see Fig. S1 in Supplementary Materials). Across districts, bromine soil concentrations were on average $14.6 \mathrm{mg} / \mathrm{kg}$ and varied by a factor of 130 from minimum to maximum. As far as in Russia there are no any regulations for bromine in soils, we cannot conclude whether bromine concentrations found in soils meet or exceed a standard level.

In the soils of different districts of Tomsk oblast, various correlations of bromine with other chemical elements were found, which might be related to numerous factors. First, each district is characterized by non-identical natural and anthropogenic conditions. Secondly, soils vary considerably in their composition, characteristics, water regime, humus content, etc. All these aspects can influence both bromine occurrence forms and its migration and reactivity capacities in soils. For example, high variability in bromine soil concentrations of Tomsky district indicates a possible contribution from anthropogenic sources that is supported by the fact that bromine anomalies here are identified near pharmaceutical and petrochemical production plants,
Table 2 Landscape parameters used for characterization of Tomsk region in USEtox 2.02

\begin{tabular}{|c|c|c|}
\hline Parameter & Value & Reference \\
\hline \multicolumn{3}{|l|}{ Continental scale } \\
\hline $\begin{array}{l}\text { Area land, } \mathrm{km}^{2} \\
\text { Area fraction } \\
\text { natural soil }\end{array}$ & $\begin{array}{l}314000 \\
0.937\end{array}$ & \multirow{2}{*}{$\begin{array}{l}\text { Territorial body of the Federal State Statistics Service of } \\
\text { the } \\
\text { Tomsk region (2019) }\end{array}$} \\
\hline Area fraction ${ }_{\text {agricultural soil }}[-]$ & 0.044 & \\
\hline Rain rate, mm/year & 568 & Evseyeva (2001) \\
\hline Fraction run off $[-]$ & 0.464 & Adapted from USEtox 2.02 for Central Asia \\
\hline Fraction infiltration & 0.269 & Adapted from USEtox 2.02 \\
\hline Human population, capita & 1.08 million & $\begin{array}{l}\text { Territorial body of the Federal State Statistics Service of } \\
\text { the } \\
\text { Tomsk region (2019) }\end{array}$ \\
\hline \multicolumn{3}{|l|}{ Urban scale } \\
\hline Area land, $\mathrm{km}^{2}$ & 33.6 & Calculated in USEtox 2.02 \\
\hline Human population, capita & $\begin{array}{l}0.183 \\
\quad \text { million }\end{array}$ & $\begin{array}{l}\text { Territorial body of the Federal State Statistics Service of } \\
\text { the } \\
\text { Tomsk region (2019) }\end{array}$ \\
\hline \multicolumn{3}{|l|}{ Production-based intake rates } \\
\hline $\begin{array}{l}\text { Above-ground produce, } \\
\text { kg/(d capita) }\end{array}$ & 0.362 & Federal State Statistics Service (2019) \\
\hline $\begin{array}{l}\text { Below-ground produce, } \\
\mathrm{kg} /(\mathrm{d} \text { capita })\end{array}$ & 0.677 & \\
\hline Meat, $\mathrm{kg} /(\mathrm{d}$ capita $)$ & 0.167 & \\
\hline Dairy products, kg/(d capita) & 0.71 & \\
\hline Fish freshwater, $\mathrm{kg} /(\mathrm{d}$ capita $)$ & 0.0031 & Federal Agency of Fishery (2019) \\
\hline $\begin{array}{l}\text { Fish coastal marine water, } \\
\mathrm{kg} /(\mathrm{d} \text { capita })\end{array}$ & 0.046 & \\
\hline
\end{tabular}


Table 3 Statistical parameters of measured bromine concentrations in the soils of the districts of the Tomsk region $(\mathrm{mg} / \mathrm{kg})(n=384)$ and area-weighted averages across measurements ${ }^{(1)}$ (adapted from Perminova et al. 2017Table 2), complemented by district areas and calculated bromine mass in soil per district

\begin{tabular}{|c|c|c|c|c|c|c|c|c|}
\hline No. & District & Area $\left[\mathrm{km}^{2}\right]$ & $N$ & $\mathrm{C}_{\mathrm{Br}}$ & $\lambda$ & Min & Max & $\begin{array}{l}\mathrm{m}_{\text {soil }} \\
{[\text { million } \mathrm{kg}]}\end{array}$ \\
\hline 1 & Alexandrovsky & 29979 & - & $\mathrm{n} / \mathrm{a}$ & & & & - \\
\hline 2 & Kargasoksky & 86857 & - & $\mathrm{n} / \mathrm{a}$ & & & & - \\
\hline 3 & Parabelsky & 35846 & 6 & 14.8 & 1.7 & 9.0 & 22.1 & 30.71 \\
\hline 4 & Kolpashevsky & 17112 & 6 & 11.9 & 2.1 & 7.5 & 21.3 & 24.69 \\
\hline 5 & Chainsky & 7242 & 16 & 15.3 & 2.0 & 5.0 & 31.8 & 31.75 \\
\hline 6 & Molchanovsky & 6351 & 5 & 14.5 & 1.1 & 11.1 & 18.0 & 30.09 \\
\hline 7 & Krivosheinsky & 4400 & 2 & 16.8 & - & 13.0 & 20.1 & 34.86 \\
\hline 8 & Shegarsky & 5030 & 2 & 14.3 & - & 13.0 & 15.6 & 29.67 \\
\hline 9 & Kozhevnikovsky & 3908 & 33 & 18.2 & 1.5 & 0.5 & 35.8 & 37.56 \\
\hline 10 & Tomsky $^{(2)}$ & 10039 & 177 & 9.3 & 0.4 & 0.5 & 59.5 & 410.92 \\
\hline 11 & Asinovsky & 5943 & 15 & 19.7 & 1.8 & 5.0 & 31.8 & 40.88 \\
\hline 12 & Pervomaysky & 15554 & 5 & 15.6 & 3.2 & 5.0 & 23.9 & 32.37 \\
\hline 13 & Verkhneketsky & 43349 & 14 & 13.6 & 2.2 & 4.4 & 30.1 & 28.22 \\
\hline 14 & Teguldetsky & 12271 & 20 & 13.2 & 1.4 & 5.0 & 28.0 & 27.39 \\
\hline 15 & Zyriansky & 3966 & 44 & 10.8 & 1.0 & 3.9 & 34.4 & 22.41 \\
\hline 16 & Bakcharsky & 24700 & 39 & 39.4 & 1.9 & 12.1 & 64.9 & 81.76 \\
\hline
\end{tabular}

(1) $n / a$, no data available; $N$, number of samples; $C_{\mathrm{Br}}$ average of measured concentrations; $\lambda$, standard error; Min and Max, minimum and maximum measured concentrations, respectively; $\mathrm{m}_{\text {soil }}$, calculated bromine mass in soil.

${ }^{(2)}$ In this district, mostly natural soils near different industrial enterprises were taken instrument-engineering and electric-bulb factories, and a Siberian chemical plant (nuclear industry). Soil samples of the Bakcharsky district on average showed the highest bromine contents, and are also characterized by significant correlations of bromine with a large number of other elements that might potentially be explained by the presence of iron ore deposits located in this district, where the bromine in the form of rare bromides may occur in the oxidation zones of some ore deposits.

\section{Toxicity and ecotoxicity impacts of bromine}

In Table 4, we summarize residence times, human intake fractions, and characterization factors for bromine, assumed to be released as continuous emission into agricultural and natural soils, by applying the characterization methods for metal ions and organic substances.

Residence times in soil, human intake fractions representing population intake of bromine per unit emission into soil, and related characterization factors for human toxicity and freshwater ecotoxicity are substantially higher when characterizing bromine as a metal ion compared with characterizing bromine as an organic substance for both agricultural and natural soils, with residence times in the range of years versus days, and intake fractions in the range of gram intake per kilogram emitted for bromine as metal ion versus milligram intake per kilogram emitted for bromine as organic substance, respectively. Regardless of whether bromine is characterized as a metal ion or as an organic substance, human intake fractions aggregated over inhalation and ingestion, as well as characterization factors for human toxicity, are substantially higher for emissions to agricultural soils by a factor 24 to 38 compared with emissions to natural soils. This is due to the dominant role of agricultural produce compared with other exposure pathways on the intake of bromine emitted to agricultural soils.

In addition, USEtox allows identifying the main exposure pathways and routes. It shows that for the characterization of bromine in soil as either substance form, the ingestion route is dominant, four to 22 orders of magnitude higher than inhalation, and that the three dominant pathways are via dairy product (associated with the $0.8 \mathrm{~kg}$ soil taken in daily by a cow (IAEA International Atomic Energy Agency 1994)), above ground produce and below ground produce (see Table S3 in Supplementary Materials).

Table 5 presents the total mass of bromine in the region and the resulting impact scores for human toxicity and freshwater ecotoxicity calculated with USEtox 2.02 for the entire Tomsk oblast region. Part a) of this table looks at the cumulative impacts of the initial mass measured in soil, assuming that there is no additional emission taking place, whereas part b) provides the steady state impacts assuming a continuous constant emission flow into soil.

Cumulative impact scores are on average a factor 200 higher for human health impacts and a factor 20 higher for ecosystem quality impacts when characterizing bromine the same way as metal ions are characterized compared with characterizing it the same way as organic substances are characterized (Table 5a). This is directly related to higher characterization factors for bromine if characterized as a metal ion, mostly based on much longer residence times in soil. These 
Table 4 Residence time $\tau_{\text {soil }}$, human intake fraction $\mathrm{iF}$, and characterization factors $\mathrm{CFs}$ for $\mathrm{Br}_{2}$ emissions in agricultural and natural soils as calculated with USEtox $2.02^{(1)}$

\begin{tabular}{|c|c|c|}
\hline Parameter & $\mathrm{Br}_{2}$ treated as metal ion & $\mathrm{Br}_{2}$ treated as organic substance \\
\hline \multicolumn{3}{|c|}{ Emission to agricultural soil } \\
\hline$\tau_{\text {soil }}$ & 17.12 years & 27.5 days \\
\hline iF & $7.06 \mathrm{~g}_{\mathrm{Br} \text { intake }} / \mathrm{kg}_{\mathrm{Br} \text { emitted }}$ & $30.59 \mathrm{mg}_{\mathrm{Br} \text { intake }} / \mathrm{kg}_{\mathrm{Br} \text { emitted }}$ \\
\hline $\mathrm{CF}_{\text {hum }}$ & $2.43 \times 10^{-3} \mathrm{DALY} / \mathrm{kg}_{\mathrm{Br} \text { emitted }}$ & $1.05 \times 10^{-5} \mathrm{DALY} / \mathrm{kg}_{\mathrm{Br} \text { emitted }}$ \\
\hline $\mathrm{CF}_{\mathrm{eco}}$ & $30181 \mathrm{PDF} \mathrm{m}^{3} \mathrm{~d} / \mathrm{kg}_{\mathrm{Br} \text { emitted }}$ & $2707 \mathrm{PDF} \mathrm{m} \mathrm{m}^{3} \mathrm{~d} / \mathrm{kg}_{\mathrm{Br} \text { emitted }}$ \\
\hline \multicolumn{3}{|c|}{ Emission to natural soil } \\
\hline$\tau_{\text {soil }}$ & 17.12 years & 27.5 days \\
\hline $\mathrm{iF}$ & $0.29 \mathrm{~g}_{\mathrm{Br} \text { intake }} / \mathrm{kg}_{\mathrm{Br} \text { emitted }}$ & $0.79 \mathrm{mg}_{\mathrm{Br} \text { intake }} / \mathrm{kg}_{\mathrm{Br} \text { emitted }}$ \\
\hline $\mathrm{CF}_{\text {hum }}$ & $9.98 \times 10^{-5} \mathrm{DALY} / \mathrm{kg}_{\mathrm{Br} \text { emitted }}$ & $2.75 \times 10^{-7} \mathrm{DALY} / \mathrm{kg}_{\mathrm{Br} \text { emitted }}$ \\
\hline $\mathrm{CF}_{\mathrm{eco}}$ & $30181 \mathrm{PDF} \mathrm{m}^{3} \mathrm{~d} / \mathrm{kg}_{\mathrm{Br} \text { emitted }}$ & $2707 \mathrm{PDF} \mathrm{m}^{3} \mathrm{~d} / \mathrm{kg}_{\mathrm{Br} \text { emitted }}$ \\
\hline \multicolumn{3}{|c|}{$\begin{array}{l}{ }^{(1)} \tau_{\text {soil }} \text {, residence time of } \mathrm{Br}_{2} \text { in soils extracted from the matrix of USEtox fate factors (in unit of time); iF, human } \\
\text { intake fractions aggregated over inhalation and ingestion (in mass of } \mathrm{Br}_{2} \text { taken in by human population per kg of } \\
\mathrm{Br}_{2} \text { emitted to soil); } \mathrm{CF}_{\text {hum }} \text {, characterization factor for humans (in disability-adjusted life years (DALY) per kg of } \\
\mathrm{Br}_{2} \text { emitted to soil); } \mathrm{CF}_{\text {eco }} \text {, characterization factor for freshwater ecosystems (potentially disappeared fraction } \\
\text { (PDF) of freshwater ecosystem species integrated over } \mathrm{m}^{3} \text { water volume and days of exposure duration per kg of } \\
\mathrm{Br}_{2} \text { emitted into soil) }\end{array}$} \\
\hline
\end{tabular}

results demonstrate the importance of correctly characterizing fate transport and chemical transformation processes for substances, as we discuss in more detail below. It should be noted that it is only when considering bromine as metal ion that the residence time in soil of 17.12 years (Table $5 \mathrm{~b}$ ) is high enough to explain the observed soil concentrations. If bromine were mostly available in soils as organic substance form, the observed soil levels would imply an emission of more than 1 million of $\mathrm{Br} \mathrm{kg} / \mathrm{d}$, which is not realistic.

Considering the case of the metal ion, the initial masses in soil are estimated by this model to generate impacts in the order of magnitude of 73500 DALY (Table 5a) for the entire regional population of 1.26 million, thus - as the first screening - an average of 0.06 DALY per person or in the order of 20 days of life lost per person on average, with $90 \%$ of the impact occurring within the next 40 years.

If continuous emissions would occur, maintaining the same measured levels in agricultural soil on the long term, the human health damages would amount to $11.8 \mathrm{DALY} / \mathrm{d}$ in the region, corresponding to an order of magnitude of 100 days of life lost over lifetime, where in all cases a life expectancy of 84 years is assumed in line with the Global Burden of Disease study series. As a screening indication, the steady state level of $11.8 \mathrm{DALY} / \mathrm{d}$ (Table 5b) corresponds to 4.4 new non-cancer disease cases per day for the 1.26 million inhabitants in the region; that is an incidence level of 126 non-cancer disease cases per 100,000 inhabitants per year associated with levels of bromine in soil. These numbers are associated with high uncertainties, especially due to the uncertainty of the toxicity effect factor, similarly to the factor 400 uncertainty reported by Fantke et al. (2012) for the total pesticide impacts in Europe (estimated at $2.4 \mathrm{~h}$ lost over lifetime per person). As a comparison element, ambient particulate matter impacts are estimated at an average (and substantially more accurate) value of 600 days of life lost per person over lifetime in Russia (ghdx.healthdata.org).

The spatial distribution of characterization results expressed as toxicity-related impact scores for human health and ecotoxicityrelated impact scores for ecosystem quality closely follows the spatial distribution of measured soil concentrations, regardless of whether bromine is characterized as a metal ion or as an organic substance. The exception is Tomsky district, where emissions are made to natural soil, whereas in all other districts, we are

Table 5 Initial bromine mass in soils and toxicity impact scores of bromine in Tomsk oblast as calculated with USEtox 2.02 within cumulative impacts of existing mass (a) and impacts at steady state (b) for both bromine characterized the same way as metal ions and as organic substances, respectively

a) Cumulative impacts

Cumulative impacts of existing mass characterized as metal ion Cumulative impacts of existing mass characterized as organic substance

b) Steady state impacts

Annual impact of steady state flow characterized as metal ion

Annual impact of steady state flow characterized as organic substance

$$
\begin{aligned}
& m_{\mathrm{Br} \text { in soil }} \\
& {\left[\mathrm{kg}_{\mathrm{Br} \text { emitted }}\right]} \\
& 3.03 \times 10^{7} \\
& 3.03 \times 10^{7}
\end{aligned}
$$

$\dot{m}_{\mathrm{Br}}$ in soil

$\left[\mathrm{kg}_{\mathrm{Br} \text { emitted }} / \mathrm{d}\right]$

$3.03 \times 10^{7} /(17.12 \times 365)=4850$

$3.03 \times 10^{7} /(27.5)=1.1 \times 10^{6}$

$\begin{array}{ll}I S_{\text {hum }} & I S_{\text {eco }} \\ {[\text { DALY] }} & {\left[\text { PDF m }{ }^{3} \mathrm{~d}\right]} \\ 73530 & 9.1 \times 10^{11} \\ 320 & 8.2 \times 10^{10}\end{array}$

IS $\dot{S}_{\text {hum }}$ [DALY/d]

IS eco $\left[\mathrm{PDF} \mathrm{m}^{3}\right]$

11.8

$1.5 \times 10^{8}$

11.6

$3.0 \times 10^{9}$ 
considering agricultural soils. This results in a very low impact score for human health in the Tomsky district, as impacts related to agricultural produce only play a minor role after emission to natural soil, even though the back-calculated emission mass is one order of magnitude higher compared with all other districts related to the much higher considered volume for natural soils in this region. On the other hand, Tomsky district shows the highest score for freshwater ecosystem impacts compared with all other districts, which is also related to the fact that emissions are assumed to be to natural soil in this region. Based on these results, impact scores for all considered districts can be ranked separately for human toxicity-related impacts and for freshwater ecotoxicityrelated impacts, as shown in Fig. 2.

When ranking the different districts according to their impact scores for human toxicity and freshwater ecotoxicity impacts, our starting point is again the measured concentrations in soil. While bromine concentrations in natural soils of Tomsky district were lowest among all sampled regions, the volume of natural soil in this district is assumed to be much larger than the volume of agricultural soil, which leads to a higher back-calculated mass in natural soil and consequently results in higher potential impacts on ecosystems than in all other districts. This picture is reversed for human impacts, which are dominated by emissions into agricultural soil across all the districts (Fig. 2).

Ratios of human toxicity-related impact scores for each district and the highest impact score across districts indicate

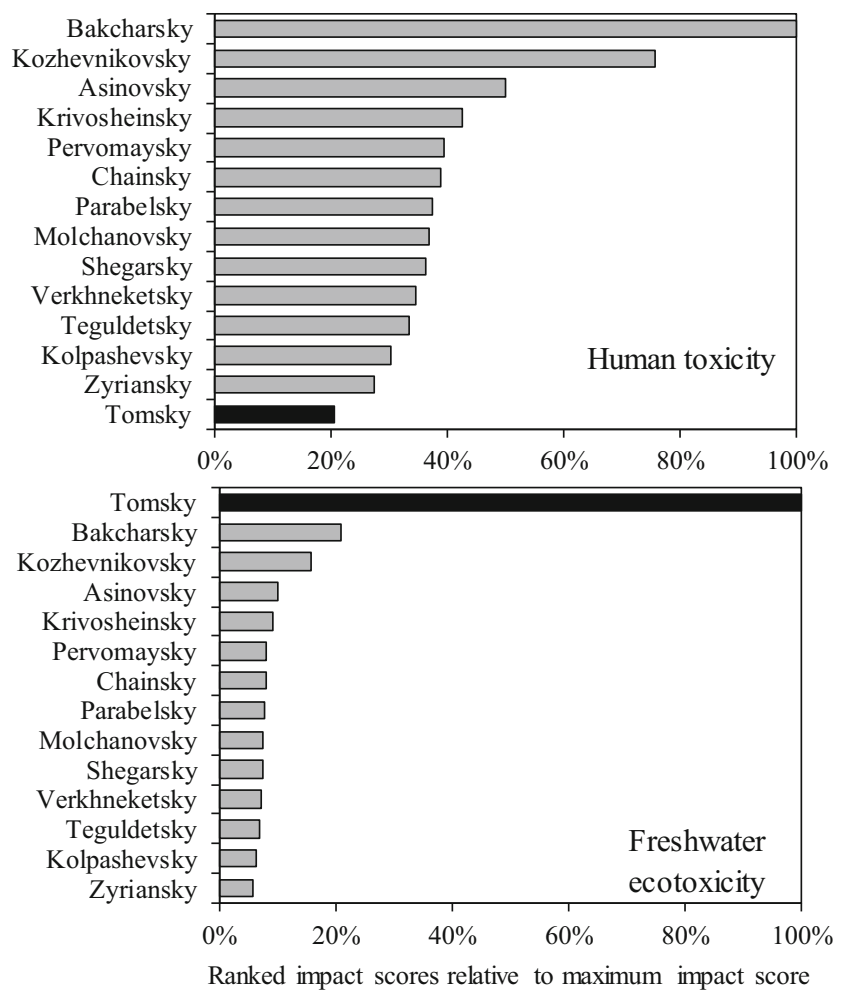

Fig. 2 Ranking of Tomsk oblast districts according to the ratio of their impact scores for human toxicity and freshwater ecotoxicity and the maximum impact scores across all districts, respectively. Black bars indicate natural soil; gray bars indicate agricultural soil that the Bakcharsky district shows the highest potential for impacts on human health related to the highest bromine concentrations in agricultural soils, while the lowest potential impacts on human health are seen for the Tomsky district for emissions to natural soil. For all districts except Tomsky, emissions are into agricultural soil and ranking across districts therefore consistently follows the difference in measured soil concentrations (Fig. 2, top).

In contrast to the ranking of human toxicity impacts, ratios of freshwater ecotoxicity-related impact scores for each district and the highest impact score across districts show that the Tomsky district has the highest impacts on ecosystem quality following emissions to natural soil, while all other districts show consistently lower impacts following emissions to agricultural soil in line with the distribution of measured soil concentrations (Fig. 2, bottom).

These results stress the importance of properly defining the emission compartment, and related exposure pathways for humans and ecosystems.

\section{Discussion}

\section{Applicability and limitations of analytical techniques}

The INAA technique, applied in the study of Perminova et al. (2017) describing measured soil concentration, results as input to calculate bromine mass in soils of different regions. It determines total amounts of chemical elements regardless of their chemical and physical forms (liquid, solid, or gaseous) or oxidation state. Therefore, elements present in as ions, for example, are all determined as the generic form of the element. In the present study, relying on measured bulk bromine concentrations in soil as starting point, however, is a considerable limitation for identifying and potentially mitigating emission source contributions of the various emission forms to overall brominerelated soil pollution. This is because chemical form and kinetic pathways of emissions of bromine-related compounds are currently not considered when measuring bulk bromine concentrations. These pathways are complex and can have a significant influence on final pollution levels and related impacts of bromine, which is itself not emitted in its elemental form.

In addition, for toxicity characterization, we need to consider which fraction of bromine in soil is bioavailable, while the widely applied INAA technique only allows for determining total amounts of bromine in soils. Bioavailability in our study is hence accounted for as part of the environmental fate calculations implemented in the used toxicity characterization model.

To address the limitations of the INAA technique, another analytical method could be tested allowing for quantitative determination of different forms of bromine. For example, for the determination of bromide in soils, several methods could be used (e.g., potentiometric measurements and 
Folgards method). However, in contrast to INAA, these methods are time-consuming and usually involve destructive solution of the sample that could influence the accuracy of the results obtained. Besides, the use of classical chemical methods of $\mathrm{Br}^{-}$determination could be highly difficult to realize, since the separation of iodide and bromide ions in environmental objects is problematic due to the proximity of their redox potentials (Konarbaeva 2008).

\section{Bromine chemistry in soil and implications for impact characterization}

As no district-specific soil characteristics have been considered in our study, differences in soil concentrations are the only relevant driver for differences in the ranking across districts in terms of potential human health and ecotoxicityrelated impact scores. However, for fully characterizing the environmental fate, exposure, and potential negative effects of bromine emissions to soil, it is thus not sufficient to know the available concentration of the overall bromine in soil. Instead, the different forms in which bromine and bromine compounds have originally been emitted have to be determined, which once again raises the question about analytical techniques to be used for the determination of bromine forms. Depending on the application of the particular substance, organic bromine compounds, such as bromoethane, bromopropene or bromoacetic acid, or inorganic bromine compounds, such as hydrogen bromide, hydrobromic acid, or alkali bromides and bromates, can all be emitted to soil, leading to different in-soil bromine profiles (Konarbaeva 2008). The different bromine compounds have different physicochemical properties compared with elemental bromine, which would also have to be considered in the impact characterization. These properties affect, among other issues, the reactivity, mobility, solubility, and other possible interactions in soil, which also depend on soil characteristics. Additionally, the bromine substances emitted undergo different chemical reactions leading to a variety of secondary products, which again have specific physicochemical properties and different bioavailabilities that would also have to be taken into account in the characterization modeling. For example, inorganic bromine in soil can react with organobromine compounds through enzyme reactions, abiotic metal catalysis, and photochemical reactions (Leri and Myneni 2012).

To better characterize the environmental exposure of bromine compounds in soil, the bioavailable fraction needs to be determined. Depending on soil conditions (e.g., $\mathrm{pH}$, temperature) and interactions with soil components, such as organic matter, or other prevalent substances, the emitted bromine mass does not equal to the bioavailable bromine mass. A comparison of several studies has shown that the wide variation of bromine contents in soils can be traced back to two main factors of influence. First, bromine concentration in soil mainly depends on the soil moisture content, and second, the bromine content of soil is positively correlated with the content of soil organic matter (Flury and Papritz 1993; Neal et al. 2007; Moreno et al. 2017). Since soil properties can influence related bioaccumulation and toxicity of bromine, it is important to determine soil parameters along with bromine concentrations in soils. In our study, these parameters were not assessed at the sampling sites, constituting a limitation of the work. Further research efforts are thus required for consistently linking the effective bromine forms found in soil with their specific physico-chemical properties and reaction pathways with their respective bioaccumulation and toxicity potentials.

Besides, some bromine gases formed (like hydrogen bromide gas) are extremely soluble in water and quickly react with basic substances in soils (Kesner 1999). The resulting bromine ions do not lead to the toxicity in soils. Therefore, results obtained present an overestimation of toxicity impacts when bromine reaction chemistry in soils is not considered properly and when instead one has to rely on characterizing measured bromine soil content the same way as metal ions are characterized. A possible way to address this limitation is to report specific soil characteristics in future soil sampling results that can then be used to calibrate characterization model results.

\section{Applicability and limitations of toxicity and ecotoxicity characterization}

The most commonly used indicator for assessing potentially harmful effects of soil contamination levels in environmental studies is a standard defined as the maximum permissible concentration-MPC (Yazikov and Shatilov 2003; Chiroma et al. 2014). MPC values are usually established based on physicochemical substance properties, based on the results of biological or toxicological experiments, and are set by law or recommended by the competent bodies at local, national, or international level. However, such standards do currently not take into account transfer processes involving other environmental media or biota for relevant chemical reactions, all of which can influence possible negative effects on humans and ecosystems. Moreover, specific MPCs for bromine in soils are not currently set in Russia. Whenever MPCs were not available or cannot be used, background or Clarke values as well as literature data could, in some cases, be used as alternative instruments for assessing the contamination level. However, this is not always applicable (Bezuglova and Okolelova 2012), and usually faces the same limitations as MPCs regarding the combined consideration of fate, exposure, and toxicity aspects and pathways. In response, we demonstrated in the present study that linking measured soil concentrations to screening-level toxicity characterization results allows us to combine all the elements of the relevant impact pathways. Toxicity characterization results, however, should always be seen as being complementary to MPCs. This is 
important to ensure compliance with regulatory frameworks and at the same time to identify relevant tradeoffs between contributing pathways and aspects.

Furthermore, approaches like the one we presented here enable the comparison and ranking of results across relevant spatial regions (Tarasova et al. 2018). However, spatially different environmental conditions and their influence on impact results cannot be considered using environmental standards/limit values which are the same for the entire territory of a country, which is often criticized (Limanova 2005). This aspect is especially relevant for bromine, which shows considerable variability in migration characteristics and interactions with other substances, all of which is highly dependent on the specific environmental conditions. Besides, scaling chemical pollution and related impacts is a key issue for large countries, like for example Russia, Canada, or China. The large size of a territory often involves large differences in climatic, hydrogeological, morphological, and other conditions, which can greatly affect the impact potential of chemical pollutants on the environment or on human health within the same territory. By integrating region-specific landscape data, we could make our study more reliable in terms of representing environmental conditions.

Additional limitations occur in the characterization approach. In order to calculate time-integrated impact scores for human toxicity and ecotoxicity in different districts of Tomsk oblast, the average bromine concentration within each district was used to back-calculate the emitted mass in the respective soils. This will not reflect the actual variability in soils within a district. Related to that, neither differences in soil characteristics within nor between districts were considered, nor could the contribution of different potential sources of measured bromine in soil be back-calculated. This would be relevant for identifying and mitigating the most relevant pollutant sources in the Tomsk oblast.

Another limitation in our study is the number of trophic levels used for calculating the ecotoxicological effect factor for bromine, which is currently based only on data for one trophic level due to the limited availability of underlying data. In addition, terrestrial ecotoxicity is currently not included in the current version of the USEtox consensus model and, hence, this impact pathway needs to be included to evaluate possible impacts of bromine amounts in soil on terrestrial ecosystems including soil organisms.

Finally, in addition to exposure determination, the human toxicity dose-response factor is a main source of uncertainty that can vary considerably between individual chemicals and chemical species (Fantke et al. 2012; Fantke and Jolliet 2016).

\section{Future research required to improve bromine characterization}

Estimating human toxicity and ecotoxicity impact scores for bromine under assumed steady state conditions and by characterizing this substance currently the same way as a metal ion or as an organic substance ignores the complex but important reaction pathways of the actual emitted brominerelated compounds with their specific bioaccumulation and toxicity potentials. To improve the toxicity and ecotoxicity characterization when measured soil concentrations are given, a dynamic fate modeling approach should be followed, where emissions are not assumed continuous, but could be modeled as pulse(s) or periodic emissions (Ngole-Jeme and Fantke 2017). This would allow to emphasize further potential differences in pollutant dynamics.

In addition to changing the system's time horizon, the modeling approach regarding fate and effect has to be adapted to bromine and its compounds to improve the toxicity and ecotoxicity characterization. In contrast to organic chemicals, and for most inorganic substances, an approach mainly based on Kow is not suitable for characterizing the various environmental fate and transformation processes of bromine and related substances in soil. For example, the concentration of emitted bromide salts might not equal the bioavailable fractions of these substances, as it is strongly dependent on soil conditions such as $\mathrm{pH}$ and temperature as well as the organic matter content. This highlights the importance of soil parameters to be taken into account. In addition, the chosen approach of converting acute effect data to chronic ecotoxicity effect data with a fixed acute-to-chronic correction should be reviewed for bromine and bromine compounds. Dong et al. (2014), for instance, show that this factor for particular metals varies substantially, especially for different tested trophic levels or species. Overall, our characterization approach can serve as the first screening of bromine impacts on humans and the environment, but will have to be linked to specific bromine emissions in order to refine the assessment.

\section{Conclusions}

Our study demonstrates how measured concentrations of chemicals in soil can operationally be combined with screening-level toxicity and ecotoxicity characterization models tailored toward a specific region of interest, based on adapting region-specific landscape data. This approach suggests considering fate and exposure processes as well as related potential human toxicity and ecotoxicity impacts in environmental studies, thereby adding an important sustainabilityrelated dimension that is required to assess and evaluate possible trade-offs between impacts and regions and ultimately linking such impacts to physical limits for chemical pollution to achieve environmental sustainability (Fantke and Illner 2019). Region-specific landscape data together with analytical techniques for identifying bromine concentrations in soils allows different considered districts to be ranked according to the potential impacts on ecosystems and human health caused 
by their different soil concentration levels. The approach followed, however, currently lacks any consideration of the complex soil chemistry of emitted bromine compounds, which is required for more accurate toxicity impact factors. Hence, existing toxicity characterization models need to be adapted in terms of considering the chemical reaction and transfer pathways of bromine and other inorganic compounds from emission to the affected receptors, and in terms of considering chemical species-specific toxicity information. Overall, our approach already helps complementing existing evaluations of soil pollutant levels with information on potential toxicity-related impacts on humans and ecosystems, and outlines how characterization models should better account for reaction kinetics of inorganic substances (Kirchhübel and Fantke, 2019). This is an important input to inform pollutant mitigation strategies in regions like the Tomsk oblast. Lastly, the combined consideration of fate, exposure, and (eco-)toxicity impacts could be considered in some standardization processes, by contributing to cover certain missing existing limits.

Funding information This research was supported by the Marie Curie project Quan-Tox (grant agreement no. 631910), funded by the European Commission under the Seventh Framework Programme.

\section{References}

Banks D, Adam AM, Bayliss V, Hogg GM, Bleuten W, Dees M, Karnachuk OV, Le Blansch K, Marquand J (2000) Environmental protection in the Tomsk region of the Russian Federation: a case study. Environ Manag 26:35-46. https://doi.org/10.1007/ s002670010069

Bezuglova OS, Okolelova AA (2012) On the normalization of arsenic content in soils (in Russian). Zhivye biokosnye sist 1:1-11.

Bumbalova A, Havranek E, Harangozo M, Riečanská E, Dejmkova E (1991) Multielement XRF-analysis of blood from patients with dilated cardiomyopathy. J Radioanal Nucl Ch 153:257-265. https:// doi.org/10.1007/BF02202645

Chemical Encyclopedia (1988) In: Knunyants IL (ed) 5 volumes (in Russian), vol 1. Soviet Encyclopedia, Moscow, p 623

Chiroma TM, Ebewele RO, Hymore FK (2014) Comparative assessment of heavy metal levels in soil, vegetables and urban grey waste water used for irrigation in Yola and Kano. Int Ref J Eng Sci 3:1-9.

Dong Y, Gandhi N, Hauschild MZ (2014) Development of comparative toxicity potentials of 14 cationic metals in freshwater. Chemosphere 112:26-33. https://doi.org/10.1016/j.chemosphere.2014.03.046

Ehmann W, Vance D (1996) Studies of trace element involvement in human disease by in vitro activation analysis. J Radioanal Nucl Ch 203:429-445. https://doi.org/10.1007/BF02041521

Emsley J (1989) The elements. Clarendon, Oxford

Evseyeva NS (2001) Geography of Tomsk oblast (in Russian). Nature and Natural Resources. Tomsk: TSU, 2001, 223 p.

Fan SM, Jacob DJ (1992) Surface ozone depletion in Arctic spring sustained by bromine reactions on aerosols. Nature 359:522-524. https://doi.org/10.1038/359522a0

Fantke P, Illner N (2019) Goods that are good enough: introducing an absolute sustainability perspective for managing chemicals in consumer products. Curr Opin Green Sustain Chem 15:91-97. https://doi.org/10.1016/j.cogsc.2018.12.001

Fantke P, Jolliet O (2016) Life cycle human health impacts of 875 pesticides. Int J Life Cycle Assess 21:722-733. https://doi.org/10.1007/ s11367-015-0910-y

Fantke P, Friedrich R, Jolliet O (2012) Health impact and damage cost assessment of pesticides in Europe. Environ Int 49:9-17. https://doi. org/10.1016/j.envint.2012.08.001

Fantke P, Bijster M, Guignard C et al. (2017) USEtox ${ }^{\circledR} 2.0$ Documentation (Version 1). USEtox ${ }^{\circledR}$ Team, Kgs. Lyngby, Denmark. http://doi.org/10.11581/DTU:00000011

Fantke P, Aylward L, Bare J, Chiu WA, Dodson R, Dwyer R, Ernstoff A, Howard B, Jantunen M, Jolliet O, Judson R, Kirchhübel N, Li D, Miller A, Paoli G, Price P, Rhomberg L, Shen B, Shin HM, Teeguarden J, Vallero D, Wambaugh J, Wetmore BA, Zaleski R, McKone TE (2018a) Advancements in life cycle human exposure and toxicity characterization. Environ Health Perspect 126:125001. https://doi.org/10.1289/EHP3871

Fantke P, Aurisano N, Backhaus T, Bulle C, Chapman PM, Cooper CA et al (2018b) Toward harmonizing ecotoxicity characterization in life cycle impact assessment. Environ Toxicol Chem 37:29552971. https://doi.org/10.1002/etc.4261

Federal Agency of Fishery (2019) Available online (in Russian) http:// www.fish.gov.ru/. Accessed: 20-Jan-2018

Federal State Statistics Service (2019) Available online (in Russian) http://www.gks.ru/wps/wcm/connect/rosstat main/rosstat/ru/ statistics/publications/catalog/doc_1286360627828 Accessed: 20Jan-2018

Filov VA (1988) Harmful chemicals. Inorganic compounds of elements of Groups I-IV (in Russian): In Filov, V.A. (Ed.), Chemistry, 260.

Flury M, Papritz A (1993) Bromide in the natural environment: occurrence and toxicity. J Environ Qual 22(4):747-758. https://doi.org/ 10.2134 jeq1993.00472425002200040017x

Gandolli SD (1999) The dictionary of substances and their effects. Edited by: Royal Society of Chemistry, London, 7 Volumes

GN 2.1.5.1315-03 (2003) "Maximum permissible concentrations (MPC) of chemical substances in the water of water bodies of drinking, household cultural-community water use", Hygienic norms, Applied 30 Avril 2003, № 78 (in Russian), Moscow

GN 2.1.6.1338-03 (2003) "Maximum permissible concentration (MPC) of the pollutants in the atmospheric air of the inhabited areas", Hygienic norms (in Russian), Moscow

GN 2.2.5.1313-03 (2003) "Maximum permissible concentrations (MPC) for hazardous substances in workplace air", Health Standars, Approved 27 April 2003 (in Russian), Moscow.

GOST 17.4.4.02-84 (1984) "Protection of the nature. Soils. Methods of sampling and sample preparation for chemical, bacteriological, helminthological analysis", Standard, Introduced 19 December (in Russian), Moscow

Greenwood NN, Ershno A (2008) Chemistry of elements: in 2 volumes (in Russian). Binom, 670 p.

Heijungs R (1995) Harmonization of methods for impact assessment. Environ Sci Pollut R 2:217-224. https://doi.org/10.1007/ BF02986769

Henderson AD, Hauschild MZ, van de Meent D, Huijbregts MAJ, Larsen HF, Margni M, McKone TE, Payet J, Rosenbaum RK, Jolliet O (2011) USEtox fate and ecotoxicity factors for comparative assessment of toxic emissions in life cycle analysis: sensitivity to key chemical properties. Int J Life Cycle Assess 16:701-709. https:// doi.org/10.1007/s11367-011-0294-6

IAEA International Atomic Energy Agency (1994) Handbook of parameter values for the prediction of radionuclide transfer in temperate environments. Technical reports series No.364. International Atomic Energy Agency, Vienna. STI/DOC/010/364, 87 p. 
IAEA International Atomic Energy Agency (2010) Handbook of parameter values for the prediction of radionuclide transfer in terrestrial and freshwater environments. Technical reports series No 472. International Atomic Energy Agency, Vienna. STI/DOC/010/472, $208 \mathrm{p}$

IUCLID (2000) Bromine, in European Commission. European Chemicals Bureau:1-49

Kabata-Pendias A (2010) Trace elements in soils and plants. CRC press

Kennedy Jr WE, Strenge DL (1992) Residual radioactive contamination from decommissioning: volume 1, technical basis for translating contamination levels to annual total effective dose equivalent. Richland, WA: Pacific Northwest Laboratory; prepared for US Nuclear Regulatory Commission. NUREG/CR-5512-Vol.1, United States.

Kesner M (1999) Bromine and bromine compounds from the Dead Sea (Ch.6). Israel products in the service of people Weizmann Institute of Science the Ministry of Education and Dead Sea Bromine Group, 207-275 pp.

Konarbaeva GA (2008) The halogens in the natural objects of the south of Western Siberia (in Russian). Dissertation, Novosibirsk, 365 p.

Leri AC, Myneni SC (2012) Natural organobromine in terrestrial ecosystems. Geochim Cosmochim Ac 77:1-10. https://doi.org/10.1016/j. gca.2011.11.012

Lide DR (1993) Basic laboratory and industrial chemicals: a CRC quick reference handbook. CRC Press, $384 \mathrm{p}$.

Limanova EG (2005) Methods of environmental regulation in Russia and abroad: analysis of the choice of environmental policy instruments and their effectiveness (in Russian). Mir economiki i upravleniya $5(2): 1-18$

McCall AS, Cummings CF, Bhave G, Vanacore R, Page-McCaw A, Hudson BG (2014) Bromine is an essential trace element for assembly of collagen IV scaffolds in tissue development and architecture. Cell 157:1380-1392. https://doi.org/10.1016/j.cell.2014.05.009

Moreno J, Fatela F, Leorri E, Moreno F, Freitas MC, Valente T, Araújo MF, Gómez-Navarro JJ, Guise L, Blake WH (2017) Bromine soil/ sediment enrichment in tidal salt marshes as a potential indicator of climate changes driven by solar activity: new insights from $\mathrm{W}$ coast Portuguese estuaries. Sci Total Environ 580:324-338. https://doi. org/10.1016/j.scitotenv.2016.11.130

Nazer IK, Hallak AB, Abu-Gharbieh WI, Saleh NS (1982) Bromine residues in the soil and fruits of certain crops after soil fumigation with methyl bromide. J Radioanal Chem 74:113-116. https://doi. org/10.1007/BF02520364

Neal C, Neal M, Hughes S, Wickham H, Hill L, Harman S (2007) Bromine and bromide in rainfall, cloud, stream and groundwater in the Plynlimon area of mid-Wales. Hydrol Earth Syst Sc 11:301312. https://doi.org/10.5194/hess-11-301-2007

Ngole-Jeme VM, Fantke P (2017) Ecological and human health risks associated with abandoned gold mine tailings contaminated soil. PLoS One 12:e172517. https://doi.org/10.1371/journal.pone. 0172517

Pehrsson K, Lins LE (1983) The role of trace elements in uremic heart failure. Nephron 34:93-98. https://doi.org/10.1159/000182989

Perminova TA, Baranovskaya NV, Laratte B, Zhornyak LV, Sudyko AF (2017) Bromine in the soils of Tomsk region (in Russian). Bulletin of the Tomsk Polytechnic University. Geo Assets Engineering 328:33-45

Rikhvanov LP, Yazikov E, Sukhikh J, Baranovskaya N et al (2006) Ecogeochemical features of natural environments of Tomsk district and diseases of the population (in Russian). Tandem-Art, Tomsk

Rosenbaum RK, Bachmann TM, Gold LS, Huijbregts MAJ, Jolliet O, Juraske R, Koehler A, Larsen HF, MacLeod M, Margni M, McKone TE, Payet J, Schuhmacher M, van de Meent D, Hauschild MZ (2008) USEtox - the UNEP-SETAC toxicity model: recommended characterisation factors for human toxicity and freshwater ecotoxicity in life cycle impact assessment. Int J Life Cycle Assess 13:532-546. https://doi.org/10.1007/s11367-008-0038-4

Tarasova N, Makarova A, Fantke P, Shlyakhov P (2018) Estimating chemical footprint: contamination with mercury and its compounds. Pure Appl Chem 90:857-868. https://doi.org/10.1515/pac-20171102

Territorial body of the Federal State Statistics Service of Tomsk region (2019) Available online (in Russian): http://tmsk.gks.ru/wps/wcm/ connect/rosstat_ts/tmsk/ru/statistics/ Accessed: 20-Jan-2018

US Environmental Protection Agency (2005) Human health risk assessment protocol for hazardous waste combustion facilities. Appendix A-2. US Environmental Protection Agency, Washington, D.C. EPA530-R-05-006

US Environmental Protection Agency OPPTS (2010) Bromine final registration review decision case 4015. US Environmental Protection Agency, Washington D.C. EPA-HQ-OPP-2009-0167; FRL$8811-4$

Valdés A, Zanobetti A, Halonen JI, Cifuentes L, Morata D, Schwartz J (2012) Elemental concentrations of ambient particles and cause specific mortality in Santiago, Chile: a time series study. Environ Health 11(82). https://doi.org/10.1186/1476-069X-11-82

Van Leeuwen FXR, Den Tonkelaar EM, Van Logten MJ (1983) Toxicity of sodium bromide in rats: effects on endocrine system and reproduction. Food Chem Toxicol 21:383-389. https://doi.org/10.1016/ 0278-6915(83)90092-3

Vinogradov AP (1939) Iodine in sea ooze. On the origin of iodinebromine waters in oil — bearing areas (in Russian). Proceedings of the biogeochemical laboratory of the Academy of Sciences of the USSR 5:19-32

Vinogradov AP (1957) Geochemistry of rare and trace chemical elements in soils (in Russian). Publishing House of the USSR Academy of Sciences, $230 \mathrm{p}$.

Westh TB, Hauschild MZ, Birkved M, Jørgensen MS, Rosenbaum RK, Fantke P (2015) The USEtox story: a survey of model developer visions and user requirements. Int J Life Cycle Assess 20:299-310. https://doi.org/10.1007/s11367-014-0829-8

World Health Organization (1988) Bromide ion. In; Pesticide residues in food-1988 evaluations. Part II-Toxicology. Rome, Food and Agriculture Organization of the United Nations (FAO Plant Production and Protection Paper 93/2

World Health Organization (2009) Bromide in drinking water. Background document for development of WHO guidelines for drinking-water quality. World Health Organization, Geneva, Switzerland. WHO/HSE/WSH/09.01/6

World Health Organization (2011) Guidelines for drinking-water quality. World Health Organization, Geneva, Switzerland. ISBN 9789241548151

Yamada Y (1968) Occurrence of bromine in plants and soil. Talanta 15: 1135-1141. https://doi.org/10.1016/0039-9140(68)80036-0

Yazikov EG, Shatilov AU (2003) Geoecological monitoring (in Russian). TPU, Tomsk

Yoffe D, Frim R, Ukeles SD, Dagani MJ, Barda HJ, Benya TJ, Sanders DC (2013) Bromine compounds. Ullmann's Encyclopedia of Industrial Chemistry, 1-31 pp. https://onlinelibrary.wiley.com/doi/ abs/10.1002/14356007.a04_405.pub2

Yuita K (1983) Optimization of radioactivation analysis for the determination of iodine, bromine, and chlorine contents in soils, plants, soil solutions and rain water. Nogyo Gijutsu Kenkyusho Hokoku, B: Dojo Hiryo 35:73-110

Yuita K, Nobusawa Y, Shibuya M, Aso S (1982) Iodine, bromine and chlorine contents in soils and plants of Japan: I. Iodine, bromine and chlorine contents in soils and plants of the basin of the Miomote River. Soil Sci Plant Nutr 28:315-336. https://doi.org/10.1080/ 00380768.1982 .10433648 
Zhornyak LV, Osipova NA, Yazikov EG, Demidova KE, Osipov KY (2016) Geochemical peculiarities of soils in Tomsk areas of industrial enterprises locations. In 22nd International symposium on atmospheric and ocean optics: atmospheric physics. International Society for Optics and Photonics 10035:100354H https://doi.org/ 10.1117/12.2249317

Kirchhübel N, Fantke P (2019) Getting the chemicals right: Toward characterizing toxicity and ecotoxicity impacts of inorganic substances. J Cleaner Prod. http://doi.org/10.1016/j.jclepro.2019.04.204
Global Health Data Exchange (2019) Available online http:// ghdx.healthdata.org/ Accessed: 20-Jan-2018 